\title{
De-Communization of Childhood. Introduction to Research on Transformations of the Discourse on Child and Childhood in Post-Communist Poland
}

\author{
Pawel Walczak \\ Ph.D., Assistant Professor, University of Zielona Góra (Zielona Góra, Poland) \\ E-mail: p.walczak@ifil.uz.zgora.pl \\ ORCID: 0000-0002-8541-0396
}

\begin{abstract}
The article is devoted to the phenomenon of "childhood de-communization" as a process of changing the way of childhood's conceptualizing and social practices related to childhood during the political transformation. The aim of the article is to design and justify research revealing changes in discourse about child and childhood in science and culture in post-communist Poland. Referring to the achievements of contemporary humanities and social sciences, a child and childhood are assumed as a socio-cultural construct that its representations are present in the texts of culture and science. This kind of research reveals the relationship between the concepts of a child and childhood and social practices aimed at the child. The subject of the research project has been designated in the area of education, law and the so-called private (subjective) education theories.

The article describes the methodological assumptions that have their source in the field of children studies and contemporary humanities. Particular attention is paid to historical research, the posthermeneutic trend, qualitative research related to gender studies and posthumanism. In addition, research into the "de-communization of childhood" is inspired by the concepts of Michel Foucault (1926-1984) and his analysis of the discourse of power and the work of Swiss psychoanalyst Alice Miller (1923-2010), studying the mechanisms of intergenerational transfer of negative educational concepts and so-called "black pedagogy."
\end{abstract}

Keywords: child, childhood, children studies, de-communization, post-totalitarianism, education, children's rights

Received: August 21, 2018; accepted: September 25, 2018

Future Human Image, Volume 10, 2018: 112-122.

DOI: $10.29202 /$ fhi $/ 10 / 12$

\section{Introduction}

The resolution of the Convention on the Rights of the Child is one of the most important achievements of Poland in the field of protection of children's rights. In 1978, Poland proposed to the UN Human Rights Commission adopting this convention and submitted its appropriate

(C) Walczak, Paweł, 2018 
project. The ideological basis of the project were the achievements of Polish pedagogical thought, and above all, the philosophical and educational concept of Janusz Korczak, who prior to the Second World War embodied its principles in everyday educational work. The project submitted by Poland was the basis for all work on agreeing on the final text of the convention, which was announced in 1989. The discussion that took place during the work on the creation of this document contributed to increasing the awareness of the existence of children as an separate, important social group, with specific needs, its own culture and a way of functioning in society. It turned out that this social group, although always coexisting with adults, is a kind of terra incognita for science. Since then, child and childhood has become a special area of research for the social sciences and humanities. Along with the political and social changes in Poland after 1989, during the period of political transformation, the theoretical approaches to the problems of the child and childhood as well as social practices related to children have also changed. The essence of these transformations have not yet been thoroughly investigated. In this article, I would like to justify the need for this kind of studies, determine their subject and scope, and reflect on the methodological framework of this research.

The starting point will be the definition of childhood as a subject of research. Next, I will present the basic problems and research directions that seem to be relevant to the issue under consideration. The next step will be a reflection on the methodological assumptions and research tools appropriate for this type of issues.

\section{Child and childhood as a subject of research}

Child and childhood as a subject of research, in the sense proposed in this article, is a category related to contemporary scientific practice within the humanities and social sciences. In ancient and modern times, the child was not an interesting object for a researcher interested in knowing man and his nature. It was the effect of an androcentric attitude, recognizing an adult man, usually male, as a full and perfect representation of a human nature. According to the Aristotelian formula, a child is just a "human chrysalis", an incomplete man who is only at the initial stage of development. The child was usually the subject of reflection about upbringing, or methods of supporting the child's development in such a way that it would become a full-fledged human being in the future.

The interest of researchers in children and childhood at the turn of the $19^{\text {th }}$ and $20^{\text {th }}$ centuries also does not go beyond the androcentric paradigm. Child-study ${ }^{1}$ resulted from the assumption that education should be based on a thorough knowledge of a child. Therefore, knowledge about a child, in the field of biology, psychology, and sociology is still being constructed in a pedagogical context. The creator of contemporary developmental psychology, Jean Piaget, does not go beyond this pattern of thinking. His theory of human intellectual development presupposes a biological diagram of the development of the stadium, where the adult man is considered a fully developed and fully "human" figure. On the other hand, a child is defined in

\footnotetext{
${ }^{1}$ Child study, also called paidology, was the attempt to apply the methods of modern science to the investigation of children in order to discover the laws of normal child development. Described as a study about a child, it was isolated and developed at the turn of the $19^{\text {th }}$ and $20^{\text {th }}$ centuries, covering the whole range of issues related to the child's physical and mental development, as well as the application of this knowledge to the issues of education and teaching. The creation of a child-study was related to the growing interest at the turn of the $19^{\text {th }}$ and $20^{\text {th }}$ centuries in the child's social situation and its rights as well as the development of experimental research in the field of developmental psychology [Pols, 2018; Siegel \& White, 1982].
} 
terms of "lack", some deficit. This approach has had a major impact on the perception of the child and childhood in science and in educational theory and practice of the twentieth century [Mathews, 1994].

Contemporary childhood research is trying to overcome the limiting of the current look at child and childhood. The direct impulse to create a new methodological approach in the study of child and childhood was the involvement of scientists from many fields of science in the work for the UN Convention on the Rights of the Child. It was then realized that the methodological chaos prevails in the scientific discourse about child and childhood, representatives of various fields use different, often contradictory, definitions of basic categories. There was a need to integrate research results in interdisciplinary studies, integration understood not as the sum of discoveries within individual disciplines, but as a holistic approach to children's issues that bring us closer to understanding childhood. In this way, the term «children studies» (childhood studies) was used as a postmodern, interdisciplinary trend of childhood research, the foundation of which is a research workshop enabling multidimensional, comprehensive childhood research, referring to the results and experiences of specific sciences such as psychology, sociology, pedagogy, economics, law, medicine, literary studies, and others. The fundamental goal of this research is to analyze the child's representations and representations in society and cultural products, as well as the reconstruction of his individual point of view. Children's studies are inspired by modern humanities and as such are modeled on cultural studies, which is characterized by an interdisciplinary research workshop that combines hard and soft science. The fundamental goal of this research is to analyze the social imaginations of child's nature and its representations in society and cultural products, as well as the reconstruction of his individual I collective point of view. Children studies are inspired by modern humanities and as such are modeled on cultural studies, which are characterized by an interdisciplinary research that combines hard and soft science.

The basic assumption of childhood studies is the recognition of childhood as a sociocultural construct, in contrast to childhood in the sense of biological development. Philip Aries (1914-1984) in his famous book History of childhood put forward the thesis that childhood is a socio-cultural construct that has appeared in Europe and has evolved since the seventeenth century [Aries, 1962]. On the basis of the analysis of historical materials, works of art and literature, personal diaries and memoirs, inscriptions and portraits on family tombstones, clothing and toys, he came to the conclusion that in the Middle Ages there is no representation of a child and childhood in art and literature. The child functioned in the social consciousness more as an adult miniature than as a separate social group associated with specific needs, social roles or rights.

The child as a separate figure in the social structure and childhood as an idea appeared according to Aries, in bourgeois culture at the end of the $17^{\text {th }}$ century. Along with noticing the child, there was also the oppression of adults towards children in the form of planned upbringing, education, and socialization practices. Recognizing children as a separate group, with specific needs and limited possibilities, resulted in increased concern for the shaping and upbringing of the child. Until now, children functioned in a union with the world of adults. Separation of the child resulted in subordinating the child to the adult in the education process.

It should be mentioned that Aries's book provoked a discussion, in which many researchers argued that children in all known cultures and epochs were constituted as more or less separate social category, although its age and position in society changed. Aries himself also realized that the concept of childhood probably existed in ancient culture. Aries notes, "...in the 
Neolithic age, the age classes, the Hellenistic paideia, testify to the existence of a difference between the world of children and the world of adults to which one passed through initiation or education. Medieval civilization did not feel such a difference, so there was no idea in it of moving from the world to the world" [Ariès, 1962: 236]. Nevertheless, Aries's undoubted merit is to show childhood as a socio-cultural category, socially constructed, subject to the influences of ideology, philosophy and art of a given epoch.

The category of child and childhood understood in this way allows for an extended analysis of changes in the child's identity and conceptualization of the child in the culture and scientific texts and identification of values, attitudes and social practices related to these changes towards children. Modern research on childhood reveals the processes of mutual interactions between the child's theory and broadly understood social practice. The way in which a child is conceptualized in a given society results from the way it functions in the area of care, education, civic rights, media, art, etc. On the other hand, these practices largely shape the child's self-awareness and identity, how the child understands itself and how it is perceived in society.

\section{Areas of research}

The methodological attitude developed within the framework of children's studies allows for an interesting problematization of the phenomenon described in this article as "decommunization of childhood." The subject of reflection and analysis will be the process of changes taking place in the discourse about child and childhood and in the area of social practices related to children in the period of political transformation in Poland. The main question will be: if and in what way, in parallel to systemic, political, economic and social changes, the way of describing a child in science and culture has changed and whether and how the child's social, economic and legal status has changed?

For the studies, three main social domains should be designated related to discourse about children, childhood, and the social practices team. First of all, attention should be paid to the education system and the entire discussion area about the objectives, tasks and methods of education and upbringing of children. Secondly, an important element of the discourse on children is the way the child functions in the legal system, which defines the child itself and defines the relationship between the child and the state and society. The third important area of research is something that can be defined as a private (subjective) theory of education, a set of beliefs, concepts and values related to the child, childhood and methods of education.

The basic hypothesis is the assumption of a post-totalitarian character of the transformation of the discourse on children and childhood in Poland. Capturing the essence, naming and describing of these features of discourse and social practices that determine their posttotalitarian character is the main task of the designed research. Therefore, the key research problem is, on the one hand, demonstrating which way under the influence of new scientific concepts, political and economic conditions, the definition of a child and how it functions in society have changed. On the other hand, to what extent the communist past shapes the current way of conceptualizing childhood and how it preserves and perpetuates totalitarian attitudes and axiologies in social practice, especially in the areas of education, law and private (subjective) theories of education.

One of the first and most visible changes in social practices related to the child during the political transformation in Poland were the changes in the education system. After 1990, the 
education system in Poland was reformed many times: in 1992 (program reform — introduction of religion to schools), in 1999 (change of school system - creation of junior high schools), in 2009 (program reform), in 2012 (reduction of pupil's age), in 2016 (program and structural reform - liquidation of junior high schools). Subsequent reformer teams published dozens of texts in which the needs of change were justified, citing new knowledge, new ideas, good practices, and new challenges. At the source of these ideas and knowledge are new concepts of the child and childhood and their place in the society. The research task in this area is the analysis of official documents related to individual reforms and the literature of the subject. This analysis will show how the goals of education, values, concepts of the child and childhood and the role of the state in the education and upbringing of children have changed.

In addition to the analysis of official documents related to the reforms of education and literature of the subject in the planned studies, it seems to be necessary to plan the research of the hidden curriculum in order to obtain a reliable result. Philippe Jackson [1968] introduced the theory of the hidden curriculum in education sciences. According to this concept, each school, each collective form of teaching, implements a hidden curriculum — not fully aware, unofficial set of rules, routine forms, expectations, values, which has a significant impact on the formation of children. A hidden curriculum is everything that students learn, get to know and experience in school, what is outside the official curriculum, outside of the official learning objectives, beyond what the teacher wants to teach willingly, and which is extremely important for the learning outcomes of children at school. Jackson has shown that the hidden program functions in texts contained in textbooks, languages, timetables, assessment systems, teacher expectations, assessment methods or school rituals. It is visible in the location of places, the designation of access zones, the building of corridors, the décor of buildings, as well as in the selection of wall colors. In the context of the proposed research, it should be assumed that it is at the level of the hidden curriculum that post-totalitarian attitudes and practices are maintained and consolidated. The research of the hidden curriculum includes the analysis of such areas of educational reality as the organization of school space, interpersonal relations, organizational determinants, violence (structural and symbolic), social and professional status of teachers, textbooks, curriculum and content of education and upbringing [Wren, 1999].

An interesting manifestation of changes taking place in the socio-cultural discourse on children during the political transformation in Poland are the changes that occurred in the law defining of the legal status of a child in Poland. In the last 30 years, the Penal Code has changed the number of penalties for crimes on children several times. The case law is also changed in cases where the victims are children, the courts more often resort to more severe sentences. At the same time, the requirements related to the safety of children in various institutions that take care of children or organize free time are increasing in law. In the period of systemic transformation in Poland, political and social institutions have become more attached to children's rights. In 2000, the Ombudsmen for Children ${ }^{2}$ institution was established, which takes measures to ensure full and harmonious development of the child, respecting his dignity and subjectivity. The establishment of the Ombudsman for Children meant the establishment of an independent institution, equipped with powers of control, warning and initiating nature, supporting efforts aimed at the maximum protection of children's rights. Research in this area,

${ }^{2}$ The world's first Ombudsmen for Children's office was established in Norway in 1981 and is the prototype that in the following years found its followers in many countries around the world. Currently, Ombudsmen for Children operate in over a dozen countries around the world. Depending on the country, the Ombudsman's institutions are organized differently, differently located within the state structures and have a different range of activity. 
involving the analysis of legal acts, official documents and literature on the subject, aims to show tendencies that strengthen the position of children in the social structure, increasing their subjectivity and autonomy in the Polish legal system. These tendencies are in line with trends in democratic societies. The research problem is the perception of phenomena characteristic of post-totalitarian societies in this area.

An interesting area of analysis, at the same time much more difficult to study than the transformation of discourse at the institutional and formal level, is to capture the transformation of thinking about child and childhood at the non-institutional and non-formal level. By private (subjective) theories of upbringing, I understand a set of beliefs, values and assumptions dominating in a given society concerning the goals and methods of bringing up children, which significantly shape the way children function in society. Private theories are shaped and perpetuated by the media, mass culture, and social message. They are often verbalized and concretized in various types of popular literature, numerous guides for parents and educators, television and radio broadcasts, thematic magazines.

It would be very valuable for the analyzes to follow the debate that took place in Poland regarding violence against children. Research shows a changing tendency in Poles' attitudes towards physical punishment towards children. Since the 90 s, the number of people allowing corporal punishment in raising children has significantly decreased. Public opinion polls regarding acceptance of violence used in raising a child show a clear drop in the number of people allowing various forms of physical violence in upbringing. Over the years 2008-2017 there is a downward trend. In almost a decade, there has been a drop in the approval of beating children by $14 \%$ with a simultaneous increase in disapproval by $19 \%$, although still $52 \%$ agree with the statement that "there are situations when the child needs to be spanked" [Jarosz, 2017]. These tendencies are undoubtedly an expression of new conceptualisations of childhood and related patterns of care and child's functioning in the family and society.

\section{Methodology of children studies}

The research areas outlined above require an appropriate methodology. On the borderline of contemporary humanities and social sciences, a field of knowledge has emerged that has developed research approaches suitable for the subject under study. Research on the process of "de-communization of childhood" is a part of the children studies trend using methodological tools developed by researchers representing this trend.

In spite of the assumed aim, children's studies have not yet developed any coherent or homogeneous method. We are dealing with a hybrid discourse, trying to combine different approaches, paradigms and areas of knowledge such as feminist theory, social theory, political theory, history, philosophy, theory of literature, media theory, art theory, law, economics, etc. This situation can arouse a sense of chaos, yet within this trend, we are able to distinguish several dominant methodological approaches.

\section{Historical research}

The representatives of this methodological trend in children studies share the assumption that a child and childhood is a socio-cultural construct that arises in history under the influence of ideology, philosophy, science or religion of its time (constructivism). Historical research reveals the sources and ways of representing a child and childhood in the cultural texts of a 
given historical period. The main representatives of this trend include Philip Aries, Le Goff, and Lloyd de Mause [Szymborska, 2013].

\section{Posthermenutical research}

On the basis of criticism of constructivism, a new analysis model appeared, consisting in a specific combination of adult and child perspectives. The main representatives of this current of research - Judith Butler, Robin Berstein, Chip Perkins, and John Wall, in opposition to constructivism, assume that a child is not a construct or rather an «image» but a fusion of an imagined childhood with the interpretation of this image by the child itself. The universality of the category of childhood is questioned here, paying attention to the elusive, fluid nature of the child, played out in constant reinterpretations (the child as a performance).

John Wall proposes to modify the traditional hermeneutic circle as a research method, transforming it into a hermeneutic ellipse. The hermeneutic circle privileges a more experienced researcher, for it presupposes a pre-understanding and pre-knowing of the questioner who is embedded in the context and in the experience to which he may refer. The elliptical perspective, which has two measures, differentiates the cognitive experience of an adult and a child, without making any of them more important in the process of understanding. Wall claims that the story of human experience has a chance to become authentic only when the child's point of view is taken into account [Szymborska, 2018].

\section{Qualitative research}

Qualitative research is based on a case study, a methodology developed in gender studies, known as girl-mathod / boy-method. This method assumes an analysis of specific cases that illustrate the structure and sources of culture and identity of a given society from the perspective of individual experience. From this perspective, gender becomes important - you are not just a child in a given society, you are a boy or a girl. They form a perspective affirming the subjectivity of girls or boys, their work, ontological integrity, a unique way of viewing reality and activity in the cultural and social space [Szymborska, 2016]. The main representatives of this trend are Kenneth Kidd, Jennifer Helgren, Colleen A. Vasconcelles.

\section{Posthuman studies}

Posthumanism is associated with the striving for a radical revision of the humanistic tradition shaped in European culture. An important element of criticism of humanism in the post-humanist paradigm is to emphasize the oppressive and exclusive character of humanistic thought. Among the groups excluded in the culture of humanism and at the same time being the subject of emancipation aspirations, the children are mentioned in posthumanistic literature [Murris, 2017]. The child is presented as a victim of the cult of a classical vision of human nature, where the model is a fully developed adult man, perfectly equipped with a complex of humanistic competences and virtues. According to Richard Kalm, the creator of the exopedagogy, underlying the modern philosophy of education and anthropocentric culture, is the system of discrimination and exclusion of children who do not fit into the normative, ideal pattern of culture. Thus, the posthumanistic current in childhood research assumes the child as a non-antropocentric category, which is the effect of the transition from paidocentrism to paidomorphism. Authors such as Rosi Braidotti and Midas Dekkers postulate new categories of child-hybrid, child-avatar, child-hypostasis, expressing the tendency to a new conceptualization of the child and childhood responding to the challenges of modern times. 


\section{Postsentimental research}

The postsentimental trend has grown on the basis of criticism of the Cartesian-Kantian model of rationality. This model assumes the category of a child as an irrational being subordinated to its own emotions, unable to function independently in both the cognitive and social spheres. Affective philosophy / history of childhood [Szymborska, 2018] affirms categories that go beyond the traditional cogito, revealing a sense-forming and cultureforming potential of affect, emotion and imagination. In this approach, the child appears as an interesting and competent partner in the conversation about the world.

\section{Michel Foucault - discourse analysis}

Analyzing the issue of discourse on child and childhood in the context of totalitarianism and post-totalitarianism, it is impossible not to refer to the concept of Michel Foucault. Particularly useful for the conducted analyses seems to be the consideration of intellectual tools created by the French philosopher associated with his research on social control and the power. M. Foucault conducted a critical study of social institutions in the context of the relationships he traces between power, knowledge and discourse. Describing these relations, he constructed methodological tools known as archeology of knowledge and genealogy of power. Both approaches have become an important inspiration for many researchers in the field of humanities and social sciences.

Archeology of knowledge examines the structure of discourses and their conditions uprising. He poses a question about the possible conditions for the appearance of texts recognized as scientific, he asks about the principles of knowledge creation, and inquiries about the genesis of cultural texts. It should be noted that the concept of discourse, proposed by Foucault, went beyond the traditional understanding of the term - "the discourse has been transformed into epistemological par excellence, serving not only the analysis of language, but knowledge systems" [Szacki, 2005, p. 907].

In addition to the concept of archeology, Foucault uses the category of genealogy of knowledge, because the French philosopher was inseparably linked to discourse with the power - the process of discourse production and distribution was seen as addicted and remaining in the service of power, where power means a dispersed set of social practices and beliefs grounded in the culture. According to Foucault, the structures and mechanisms of power are visible in socially created meanings - the meaning remains in close relation to the mechanisms of power. As Jerzy Szacki notes: "Every discourse is at the same time a system of power, it means imposing a certain definition of truth and falsehood, good and evil, normality and pathology, and thus the subjugation of those who would like to carry out the border between them in some other way" [Szacki, ibid.]. The task of the genealogy of knowledge is, therefore, to discover knowledge thrown out of parentheses of the dominant discourse, validation of the marginalized knowledge systems and exposing abuse in the prevailing discourse [Synowiec, 2013].

The archaeological approach reveals Foucault as the philosopher of the subject. A philosophical program is the study of the ways in which discourses and practices have transformed people into objects of a particular kind [Ball, 2010: 27]. The analysis of the concept of Jean Piaget by Valerie Walkerdine [1984] is an example of the application of archaeological approach to children's issues. It shows how Piaget's developmental psychology, which had a huge impact on $20^{\text {th }}$ century pedagogy and education, has become part of a series of science-sanctioned practices which object is a growing child. Practices such as supervision, 
observation and classification - characteristic for the area of education and childcare allow for the normalization of the child although at the same time the developing child is an object created by these practices. In the light of Foucault's theory, all practices and rules that produce and transform these practices simultaneously normalize individuals and, to some extent, create objects of a particular kind. In relation to childhood, educational practices such as assessment, programmed teaching, examination, selection, etc.), medical (vaccination, periodic examination, measurement, etc.), political (selecting children due to social origin, economic status, disciplining, etc.), create children as entities of a specific type. In this context, the basic task is to examine how the discourses about the child as a developing subject were changing during the period of political transformation in Poland and how the changes within these discourses affected the social practices sanctioned in these discourses, the subject of which is a child.

In the genealogical approach, the analytical apparatus determines the concept of powerknowledge, which allows in the historical study to discover the knowledge inscribed in the hierarchy of power. Foucault tries to show how in society discourse becomes the rate of power, how it is produced, controlled, selected, redistributed or processed. Discourse not only allows us to explain struggles and systems of domination, but also is itself the power that we try to gain [Foucault, 1981].

In the context of research into children and childhood, the genealogical approach allows to reveal and describe the mechanisms of constituting entities subject to supervision by the authorities at the micro and macro level. It seems particularly important to analyze educational institutions such as schools, kindergartens, as specific polygons, where the techniques and strategies of power and efficient governments are developed and improved. Perhaps S. J. Ball is right. when he claims that looking at education from the perspective of the Foucaultian genealogy of knowledge can show that "the present and its related practice and discourse are not as rational, humane or developed as we might think - it can shed light on what we do with our children in the name of education" [Ball, 2010: 40). Foucault's analysis of childhood can help to explain and name mechanisms that replicate and conserve totalitarian practices and axiologies in culture.

\section{Alice Miller and "black pedagogy"}

Alice Miller (1923-2010), a Swiss psychoanalyst and philosopher, was the author of several books, in which she unmasks the mechanism of violence present in the methods of education used in the past and passed down from generation to generation. She used the category of black pedagogy, by means of which she describes the influence of violence and oppressive educational methods on the attitudes, mentality and psyche of the next generations. Research on black pedagogy reveals the negative impact of some educational theories and practices that strengthen the forms and mechanisms of the child abuse by generations. This phenomenon was described by Miller as inheritance of discriminatory attitudes.

In her research, she used the biographical method, analyzed diaries and educational guides for parents and teachers. The aim of the analysis of black pedagogy is to show how teachers, children and their parents condemn themselves arbitrarily to their own enslavement. Over the course of time, especially the recent ones, different concepts appeared in the field of education: liberal, emancipation, anti-authoritative, and humanistic education. According to black pedagogy, the above views did not differ from each other, but were only a change of guard in the field of education. A. Miller concludes that upbringing is a destructive role, because it 
is an area for physical and psychological violence. Each generation designs younger types of violence for the next generation. A child beaten in childhood will do the same as an adult. Alice Miller in the famous book For Your Own Good [Miller, 2002] analyzed three specific cases: a young drug addict who committed suicide; a young father who murdered his children and Adolf Hitler. Through the study of the first years of life of these three people, she wanted to prove that the oppressive experiences from childhood influence the later attitude towards herself, others and all humanity.

Miller writes elsewhere: "I call the violent kind of upbringing abuse, not only because children are thus refused the right dignity and respect as human beings but also because such an approach to parenting establishes a kind of totalitarian regime in which it is impossible for children to perceive the humiliations, indignities, and disrespect they have been subjected to, let alone to defend themselves against them. These patterns of childhood will inevitably then be adopted by their victims and used on their partners and their own children, at work, in politics, wherever the fear and anxiety of the profoundly insecure child can be fended off with the aid of external power. It is in this way that dictators are born; these are people with a deepseated contempt for everyone else, people who were never respected as children and thus do their utmost to earn that respect at a later stage with the assistance of the gigantic power apparatus they have built up around them" [Miller, 2006, p. 28].

The method of analysis of "black pedagogy" developed by Miller allows revealing the hidden mechanisms of transmitting and perpetuating post-totalitarian beliefs and attitudes relating to children, which are essential for shaping current social practices related to childhood.

\section{Conclusions}

The aim of research on the transformation of the discourse on child and childhood in the period of political and social changes in Poland after 1989 is to track changes in the forms of child and childhood conceptualization in science and other cultural texts, and describe the mechanisms of the impact of changing discourse on social practices related to children and childhood. The basic premise for undertaking such research is the observation of deeply rooted and perpetuated convictions, attitudes and values characteristic for posttotalitarian societies in subsequent generations. In this article, I tried to determine the scope of the analysis, covering such areas of social life as education, law and private (subjective) theories of education. Methodological approaches appropriate to the subject of research have also been established and justified, having their source in the field of children studies and contemporary humanities.

Reliable studies on the de-communization of childhood can be the basis for improving social policy understood as a long-term systemic action for change in the social structure with the help of legal, economic, educational tools, institutions and qualified personnel. Understanding the mechanisms of preservation of post-totalitarian practices can contribute to building public awareness, improving the conditions of children's functioning in society.

\section{References}

Aries, Philippe, Centuries of Childhood: A Social History of Family Life. New York: Alfred A. Knopf. 1962.

Ball, Stephen J. Foucault and Education: Disciplines and Knowledge. London and New York: Rutledge, 2010. 
Foucault, Michel. The order of Dicourse. In: Untying the Text. The Post-Structuralist Reader. Robert Yang (ed.). Boston, London and Henley: Rutledge \& Kegan Paul, 1981. pp. 48-78.

Jackson, Philippe. Life in Classrooms. New York: Holt, Reinhart \& Winston, 1968.

Jarosz, Ewa. Przemoc w wychowaniu — czas z tym skończyć! Raport Rzecznika Praw Dziecka 2017, Retrieved 01/09/2018 from: http://brpd.gov.pl/sites/default/files/przemoc_w_ wychowaniu_raport_2017_0.pdf

Matthews, Gareth B. The Philosophy of Childhood, Cambridge: Harvard University Press, 1994.

Miller, Alice. For Your Own Good Hidden Cruelty in Child-Rearing and the Roots of Violence. New York: Farrar-Straus-Giroux, 2002.

Miller, Alice. The Body Never Lies: The Lingering Effects of Hurtful Parenting. New York London: W. W. Norton \& Company, 2006.

Murris, Karen. The Posthuman Child: iii, in: D. Kennedy, B. Bahler (ed.), Philosophy of Childhood Today: Explring the Boundaries, Lexington Books 2017, s. 185-197.

Pols, Hans. Child Study. Encyclopedia of Children and Childhood in History and Society. Retrieved 01/09/2018 from: http:/www.encyclopedia.com/children/encyclopediasalmanacs-transcripts-and-maps/child-study

Siegel, Alexander W., Sheldon H. White. The Child Study Movement: Early Growth and Development of the Symbolized Child. Advances in Child Development and Behavior, Vol. 17, ed. Hayne W. Reese. New York: Academic Press. 1982.

Synowiec, Aleksandra. W stronę analizy tekstu — wprowadzenie do teorii dyskursu. Zeszyty Naukowe Politechniki Śląskiej. Seria: Organizacja i Zarządzanie, vol. 65/2013 pp. 383396.

Szacki, Jerzy. Historia myśli socjologicznej. Warszawa: PWN 2005.

Szymborska, Karolina. W laboratorium Children studies. Dziecko i dzieciństwo w nowoczesnym dyskursie naukowym. Niesporek-Szamburska, B. Wójcik-Dudek (ed.), Nowe opisanie świata. Literatura i sztuka dla dzieci i młodzieży. W kręgach oddziaływań. Katowice: 2013.

Szymborska, Karolina. Children Studies jako perspektywa metodologiczna. Współczesne tendencje w badaniach nad dzieckiem. Teksty Drugie, vol. 1/2016, pp. 189-205.

Szymborska, Karolina. ChildrenStudies. D. Waloszek(ed.)EncyklopediaDzieciństwa. Retrieved 01/09/2018 from: http://encyklopediadziecinstwa.pl/index.php?title=Children_studies

Walkerdine Valerie. Developmental psychology and the child centered pedagogy. In: Henriques J. (ed.). Changing the Subject. London: Methuen. 1984. pp. 153-202.

Wren, D. J. School Culture: Exploring Hidden Curriculum. Adolescence. Vol. 34, No. 135 Fall 1999. 